\title{
OBRAZ KOŚCIOŁA KATOLICKIEGO \\ W PRASIE JUGOSŁOWIAŃSKIEJ \\ W OKRESIE DĄŻENIA WŁADZ JUGOSŁOWIAŃSKICH \\ DO ZERWANIA RELACJI ZE STOLICĄ APOSTOLSKĄ (1952)
}

\author{
PAWEŁ WAWRYSZUK
}

\begin{abstract}
Image of the Catholic church in the Yugoslav press in the period of Yugoslav authorities' efforts to break the relations with the Holy See (1952). The aim of the article is to analyse the actions taken by the Yugoslav press against the Catholic Church. The beginning of this campaign may be dated from the middle of January 1952. During the meeting of the Executive Bureau of the Central Committee of the Communist Party of Yugoslavia, Josip Broz Tito decided to break diplomatic relations with the Holy See. The press campaign focused mostly on Croatia and Slovenia, the republics with the majority of the Catholic population. The Catholic church was presented as an anti-Yugoslav factor, the Yugoslav Catholic hierarchy and its leaders, including a head of the church, Croatian bishop Alojzije Stepinac were accused of being collaborators together with the fascist regimes from the war period. On the other hand, the press avoided attacks on lower rank priests, hoping to convince them to join the pro-government associations.
\end{abstract}

Streszczenie. Artykuł przedstawia kampanię prasy jugosłowiańskiej, skierowaną przeciwko Kościołowi katolickiemu. Jej początek jest datowany na połowe stycznia 1952 roku, gdy podczas posiedzenia Komitetu Wykonawczego (Politbiura) KC Komunistycznej Partii Jugosławii, Josip Broz Tito zadecydował o zerwaniu stosunków dyplomatycznych ze Stolicą Apostolską. Główny nacisk kampanii prasowej został skierowany na Chorwację i Słowenię, gdzie katolicy stanowili większość. Gazety przedstawiały Kościół katolicki jako siłę antyjugosłowiańską i ukazywały hierarchów, na czele z chorwackim biskupem Alojzije Stepincem, jako kolaborantów reżimów faszystowskich z czasów II wojny światowej. Unikano jednak atakowania duchownych niższej rangi, chcąc przyciągnąć ich do stowarzyszeń, które współpracowały z władzami.

Author: Paweł Wawryszuk, Uniwersytet Kazimierza Wielkiego w Bydgoszczy, Wydział Historyczny, ul. Księcia Józefa Poniatowskiego 12, 85-671 Bydgoszcz, pawel.wawryszuk@gmail.com

ORCID iD: https://orcid.org/0000-0003-0351-6873

Keywords: state-church relations, communism, religion, Yugoslavia, press, communist repressions

Słowa kluczowe: relacje Państwo-Kościół, komunizm, religia, Jugosławia, prasa, represje komunistyczne

Balcanica Posnaniensia. Acta et studia, XXVIII/2, Poznań 2021, Wydawnictwo Wydziału Historii UAM, pp. 99116, ISBN 978-83-66355-84-2, ISSN 0239-4278. Polish text with summaries in English and Polish

doi.org/10.14746/bp.2021.28.22

W historiografii państw postjugosłowiańskich, jak i w polskiej, zerwanie stosunków dyplomatycznych pomiędzy Belgradem a Watykanem dnia 17 grudnia 1952 r. oraz okres go poprzedzający są dosyć dobrze opisane. Znacznie mniej szczegółowo jest przedstawiony ten proces z perspektywy prasy jugosłowiańskiej. Celem niniejszego 
artykułu jest wypełnienie tej luki poprzez analizę kampanii propagandowej w prasie jugosłowiańskiej, poprzedzającej to wydarzenie. Cezurą początkową jest 15 stycznia 1952 r., kiedy odbyło się spotkanie Politbiura KC Komunistycznej Partii Jugosławii (KPJ) z Josipem Broz-Titą na czele. Podjęto wówczas decyzję o zerwaniu stosunków dyplomatycznych ze Stolicą Apostolską oraz zapoczątkowano kampanię antykatolicką. Z kolei wraz z początkiem 1953 r. główny ciężar zainteresowania prasy jugosłowiańskiej skierowano na mającą się odbyć w marcu wizytę Tity w Wielkiej Brytanii. Kryteriami doboru przytoczonych artykułów prasowych były ich reprezentatywność oraz takie cechy, jak typ i zasięg gazety. Ostatecznie wyróżniono siedem kategorii treści. Kwerendę ułatwiał sposób opracowania tych materiałów przez Archiwum Jugosławii (Arhiv Jugoslavije) w Belgradzie, gdzie dostępny jest wykaz publikacji prasowych.

\section{GENEZA ZERWANIA RELACJI DYPLOMATYCZNYCH MIĘDZY JUGOSŁAWIĄ A STOLICĄ APOSTOLSKĄ}

Komuniści jugosłowiańscy, przejmując władzę w Jugosławii tuż po wycofaniu się wojsk okupacyjnych, rozpoczęli instalowanie nowego porządku społeczno-ekonomiczno-politycznego. Nieodzownie wiązało się to z rozprawą z faktycznymi bądź domniemanymi wrogami. Przy użyciu armii, nowoutworzonych służb bezpieczeństwa w postaci OZNY ${ }^{1}$, jeszcze przed zakończeniem wojny rozpoczęła się bezpardonowa eliminacja czetników generała Dragoljuba „Dražy” Mihailovicia, wszelkiej maści kolaboracjonistów (bądź osób za nich uznanych) z poszczególnych republik oraz zwolenników demokracji parlamentarnej. Niektóre represje miały charakter bezprawny, inne mieściły się formalnie w granicach prawa. Powołana została specjalna Państwowa Komisja ds. Rozliczania Zbrodni Sił Okupacyjnych i ich Pomocników (Državna komisija utvrđivanje zločina okupatora i njihovih pomagača - D.K.), dokumentująca zbrodnie. Wyroki wydawane były głównie przez sądy wojskowe. Oficjalnie 49245 jugosłowiańskich obywateli uznanych zostało za tzw. zdrajców wewnętrznych, choć z oczywistych względów nie jest to liczba całkowita² ${ }^{2}$.

${ }^{1}$ OZNA, Wydział Ochrony Ludu (Odeljenje za zaštitu naroda). W 1946 r. z OZNY wydzieliły się: UDBA, Służba Bezpieczeństwa Państwowego (Uprava državne bezbednosti) i KOS, Służba Kontrwywiadu (Kontraobavještajna služba). Szerzej o specyfice organizacji służb bezpieczeństwa w Jugosławii, w tym jej działalności, w szczególności w Chorwacji: B. Dimitrijević, Intelligence and security services in Tito 's Yugoslavia 1944-1966, „Istorija 20. veka” 2019, nr 2, s. 9-28; idem, Kontraobaveštajna služba na na području Hrvatske 1944-1968., [w:] Jugoslavija između ujedinjenja i razlaza. Hrvatsko-srpski odnosi u kontekstu društvenog razvoja dve Jugoslavije 1918-1991, red. B. Dimitrijević, M. Jareb, Beograd 2018, s. 141-160; K. Nikolić, Mač revolucije: OZNA u Jugoslaviji 1944-1946, Beograd 2014.

${ }^{2}$ M. Zečević, J. Popović, Dokumenti iz istorije Jugoslavije: Državna komisija za utvrđivanje zločina okupatora i njegovih pomagača iz drugog svetskog rata, t. 2, Beograd 1998, s. 290-291. Szerzej o zbrodniach komunistycznych i ich rozliczaniu: P. Wawryszuk, Jugosławia, [w:] Sprawiedliwość, zemsta i re- 
Mimo, iż w gruncie rzeczy ostrze represji było skierowane przeciwko wrogom nowego ustroju bez względu na ich narodowość, to w największym stopniu dotyczyły one Słoweńców i Chorwatów. W przypadku tych drugich chodziło o zaangażowanie w często zbrodniczą działalność Niezależnego Państwa Chorwackiego (NDH Nezavisna Država Hrvatska) w czasach okupacji, a jednym z elementów represji było oskarżenie Kościoła katolickiego o wspieranie ustaszy. Kolaboracja wielu przedstawicieli Kościoła z ówczesnymi władzami nie budziła wątpliwości, aczkolwiek z całą pewnością inne pobudki polityczne kierowały J. Titą czy też Vladimirem Bakariciem (od kwietnia 1945 r. premierem komunistycznego rządu Chorwacji) przy próbach uporządkowania relacji z poszczególnymi organizacjami wyznaniowymi ${ }^{3}$.

Kościół katolicki w Jugosławii pozostawał największą niezależną od władz organizacją. Komuniści niemal natychmiast po wyzwoleniu rozpoczęli intensywne działania w celu podporządkowania jego struktur władzy. Już 2 czerwca 1945 r. Tito z Bakariciem spotkali się w Zagrzebiu z przedstawicielami lokalnego episkopatu, podczas którego przekonywali interlokutorów o konieczności wzięcia większej odpowiedzialności Kościoła przed narodem. Przywódcy argumentowali, że instytucja kościelna adaptowała na swoje potrzeby przede wszystkim „,włoski punkt widzenia”. W przypadku większego „uniezależnienia się” od wpływów zewnętrznych, Tito obiecywał rozwiązanie dręczących stronę kościelną problemów, gdyż jak przekonywał, wszystko inne to kwestie drugorzędne $e^{4}$. Na przeszkodzie do takiego ułożenia relacji z władzami stał arcybiskup zagrzebski Alojzije Stepinac, w związku ze swoją antykomunistyczną postawą nazywany przez propagandę ,zbrodniarzem”. W oficjalnej biografii Tity pióra Vladimira Dedijera z 1953 r. napisano:

Problem odnowy nie był jedynym, przed jakim stanęła Jugosławia wraz z zakończeniem wojny. Należało do końca wcielić w życie to, o co walczył naród. A była to pełna równoprawność wszystkich narodów Jugosławii pod postacią braterstwa i jedności. Było to konieczne, biorąc pod uwagę ogromne straty wojenne, wykopanie rowów pomiędzy narodami czy wyznaniami, by osoby najbardziej odpowiedzialne za bratobójczą walkę zostały ukarane, aby uwolnić się w przyszłości od podobnych niebezpieczeństw, dla przetrwania narodu, utrzymania Jugosławii jako całości, a z drugiej strony przebaczyć tym, którzy byli tylko ślepymi narzędziami w rękach ich przywódców. Dlatego wiele osób odpowiedzialnych za zbrodnie czasu wojny musiało odpowiedzieć przed sądami, a między nimi i zagrzebski arcybiskup Alojzije Stepinac, Draža Mihailović i inni zbrodniarze wojenni ${ }^{5}$.

W zasadzie słowa te pokazują (podkreślmy datę wydania publikacji: 1953 r.), jak instrumentalnie traktowane były kwestia odpowiedzialności za zbrodnie czasu wojny

wolucja. Rozliczenia z wojna i okupacja w Europie Środkowo-Wschodniej, red. A. Paczkowski, Gdańsk 2016, s. 97-129.

${ }^{3}$ Oblicza się, że po ustaniu działań wojennych życie straciło około 30 księży katolickich, por. M. Akmadža, Katolička crkva u komunističkoj Hrvatskoj 1945-1980, Zagreb-Slavonski Brod 2013, s. 20.

${ }^{4}$ Cyt. za: M. Zacharias, Komunizm, federacja, nacjonalizmy: system władzy w Jugostawii 19431991: powstanie, przeksztatcenia, rozkład, Warszawa 2004, s. 73.

5 V. Dedijer, Josip Broz Tito. Prilozi za biografiju, Beograd 1953, s. 397-398. 
i oskarżenia o kolaboracjonizm. Nie wnikając w skomplikowaną i nie do końca jednoznaczną postawę kardynała Stepinca w czasie wojny ${ }^{6}$, warto podkreślić jeden fakt. Mianowicie, duchowny był wymieniany w pierwszym szeregu obok przywódcy czetników, pominięto natomiast np. ,architekta” zbrodniczych represji, czyli poglavnika NDH, Ante Pavelicia (uniknął on rozliczenia swojej działalności z czasów II wojny światowej), czy generała Milana Nedicia, szefa marionetkowego rządu serbskiego, który dostał się w ręce komunistów po wojnie. Ponadto, co odczytać można symbolicznie, nazwisko kardynała padało w całej ponad czterystustronicowej książce zaledwie raz (sic!), właśnie w kontekście oskarżeń i to pomimo faktu, że Stepinac spotkał się z Tito osobiście ${ }^{7}$.

A. Stepinca uwięziono we wrześniu 1945 r., wytoczono proces i ostatecznie skazano w październiku następnego roku na szesnaście lat ciężkich robót, choć do takowych nigdy nie był zmuszany. Jego działania jeszcze przed uwięzieniem, takie jak publikowanie listów duszpasterskich wspieranych przez Stolicę Apostolską, nie mogły być tolerowane przez Belgrad. Władzom udało się jednak pozyskać do współpracy niektórych dostojników kościelnych, z których najważniejszym był Svetozar Ritig, minister bez teki w rządzie chorwackim i sekretarz chorwackiej Komisji ds. Wyznań (na szczeblu federalnym była to Państwowa/Związkowa Komisja ds. Wyznań Državna/Savezna komisija za verska pitanja, $\mathrm{D} / \mathrm{SKVP}^{8}$ ). Nie doprowadziło to jednak do odebrania niezależności Kościołowi. Nieco lepsze rezultaty komuniści osiągnęli na tym w polu w Bośni i Hercegowinie ${ }^{9}$, co i tak nie przesłaniało narastania konfliktu na linii państwo-Kościół katolicki w Jugosławii.

Władze w Belgradzie stale nasilały represje wobec religii, uderzając bezpośrednio w struktury kościelne. Polegało to na konfiskatach mienia przy okazji implementacji różnego rodzaju reform, związanych ze „zmianą stosunków własnościowych” w Jugosławii, jak to eufemistycznie określał reżim. Należały do nich m.in. ustawy

${ }^{6}$ Spór, który toczy się głównie pomiędzy stroną chorwacką i serbską, odnosi się do postawy arcybiskupa A. Stepinca podczas II wojny światowej. Jego przeciwnicy podkreślają przynajmniej częściową odpowiedzialność za zbrodnie ustaszowskie, w tym tolerowanie przymusowego nawracania Serbów na katolicyzm. A. Stepinac był wikariuszem wojskowym ustaszy i członkiem parlamentu NDH. Z drugiej strony, znane są jego wypowiedzi krytykujące przemoc władz ustaszowskich w stosunku do ludności cywilnej. Więcej na ten temat: N. Žutić, Nadbiskup Stepinac. Ideologija i polityka 1934-1946, Beograd 2017; M. Akmadža, Riječju i djelom, Zagreb 2019; S. Alexander, The Triple myth: a life of archbishop Stepinac, Boulder 1987.

7 W czerwcu 1945 roku J. Broz Tito i jego współpracownicy prowadzili intensywne rozmowy z A. Stepincem (m.in. 4 czerwca Tito-Stepinac, 28 czerwca Bakarić-Stepinac) oraz przedstawicielami episkopatu; por. M. Akmadža, Katolička crkva, s. 23; B. Jandrić, Položaj katoličke crkve u Hrvatskoj u poslijeratnim godinama (1945.-1953.), „Croatica Christiana Periodica” 1998, nr 42, s. 51-52. Wszelkie istotne decyzje w sprawie A. Stepinca (m.in. o jego aresztowaniu, taktyce przesłuchań, rodzaju stawianych zarzutów) podejmowane były w ścisłym kierownictwie KPJ.

8 Więcej na temat D/SKVP: P. Wawryszuk, Działalność Państwowej / Związowej Komisji ds. Wyznań w Jugosławii w latach 1945-1971, „Dzieje Najnowsze” 2018, nr 4, s. 79-95.

9 Por. I. Lučić, Komunistički progoni katoličke crkve u Bosni i Hercegovini 1945.-1990., „National Security and the Future" 2008, nr 3(9), s. 41-71. 
o konfiskacie mienia, reformie rolnej i kolonizacji (obie z 1945 r.), nacjonalizacji (1946 r.), wywłaszczeniu (1947 r.) i inne mniej znaczące w interesującym nas obszarze $^{10}$. Te działania władz były wielkim ciosem m.in. dla instytucji kościelnych. W wyniku omawianych regulacji, zarówno Kościół katolicki, jak i Cerkiew prawosławna straciły około 85 procent swoich majątków ${ }^{11}$.

Kolejną próbą rozbicia jedności działających na terenie Jugosławii kościołów była powszechna w państwach komunistycznych praktyka tworzenia stowarzyszeń duchownych. W przypadku Islamskiej Wspólnoty Wyznaniowej była to organizacja o nazwie Ilmija, powołana do życia w 1950 r. i posiadająca oddziały w całym kraju. Prawosławne stowarzyszenia współpracujące z rządem powstały w zasadzie tuż po zakończeniu wojny, w czerwcu 1945 r. w Czarnogórze. Na szczeblu federalnym, jako związek instytucji republikańskich, rozpoczęły funkcjonowanie od 3 czerwca 1948 r. Pod koniec 1949 r. skupiały aż 70 procent wszystkich duchownych ${ }^{12}$. Taktyka ta w przypadku Kościoła katolickiego w Jugosławii okazała się jednak nieskuteczna. Stowarzyszenia co prawda powstawały, jednakże zasięg ich działalności był o wiele mniejszy, niż oczekiwały tego władze ${ }^{13}$.

Pewną nadzieję na unormowanie stosunków państwowo-kościelnych przyniósł konflikt pomiędzy KPJ a partiami komunistycznymi skupionymi w Kominformie, w czerwcu 1948 r. Szczególnie w latach 1950-1951 można było zaobserwować szereg półoficjalnych inicjatyw ze strony przedstawicieli rządu, w których często pośredniczył Ritig. Tito od początku sporu powtarzał, że ,ma czas”, że jest cierpliwy i w zasadzie „czas gra na jego korzyść”. Wydawało się, że kompromis mógł być w zasięgu ręki. Jednakże za takimi stwierdzeniami Tity, głoszonymi też przez innych ważnych decydentów jugosłowiańskich, szły działania nie do przyjęcia przez stronę kościelną. Mam na myśli nie tylko agresywne poczynania stowarzyszeń kościelnych, ale przede wszystkim kolejne utrudnienia, dotyczące niekorzystnych dla Kościoła decyzji personalnych, wykonywania obrzędów religijnych, edukacji religijnej itp. Celem tych działań było oderwanie jak największej części wiernych od Kościoła instytucjonalnego. Wobec księży „dobrze rokujących” w kontekście ich przynależności do oficjalnych stowarzyszeń, władze stosowały sprawdzone metody służb bezpieczeństwa: groźby, szantaż, fizyczne ataki.

10 Por. M. Maticka, Zakonski propisi o vlasničkim odnosima u Jugoslaviji (1944-1948), „Radovi Zavoda za hrvatsku povijest Filozofskoga fakulteta Sveučilišta u Zagrebu" 1992, t. 25, nr 1, s. $123-148$.

11 V. Velikonja, Separation \& politcal intolerance in Bosnia-Herzegovina, College Station 2003, s. 187.

12 Arhiv Jugoslavije [dalej: AJ], Savezna komisija za verska pitanja [dalej: SKVP], 144-2-33, Izvještaj sa posjete članova odbora Saveza Udruženja pravoslavnog sveštenstva FNRJ Maršalu Titu prilikom održavana Treće plenarne sjednice Saveza udruženja u Beogradu (23.12.1949), s. 1; J. Janjić, Srpska crkva u komunizmu i postkomunizmu (1945-2000), Beograd 2018, s. 88. W 1952 r. „Borba” pisała o 1700 duchownych, spośród których część uczestniczyła w pracach np. Frontu Ludowego. S. Alexander, Church and state in Yugoslavia since 1945, London 1979, s. 189.

13 Obszernie na ten temat: M. Akmadža, Biskupi, komunisti i svećenička udruženja, Zagreb-Sarajevo 2018. 
Na początku 1952 r. Stolica Apostolska, dążąc do wypracowania modus viven$d i$, przygotowała ofertę dla Jugosławii. Obejmowała ona amnestię dla duchownych, przywrócenie nauczania religijnego, zapewnienie wolności prasy religijnej i odejście od dyskryminacji religii w przestrzeni publicznej ${ }^{14}$. Tito, jako polityk ambitny, a przede wszystkim mający do dyspozycji silny argument w postaci aparatu państwowego, nie chciał zaakceptować takiej propozycji, uznając ją za swoiste ultimatum. Jego odpowiedź, nieco zbyt gwałtowna, jak później przyznał on i jego współpracownicy, w szczególności Edvard Kardelj, nastąpiła podczas spotkania Politbiura KC KPJ w dniu 15 stycznia 1952 r. Zapadła wówczas decyzja o zerwaniu stosunków dyplomatycznych ze Stolicą Apostolską. W tym samym czasie do republikańskich KC rozesłano instrukcje postępowania, stanowiące „opcję atomową" w konfrontacji z religiami w Jugosławii. Nakazano całkowicie usunąć religię ze szkół i wyłączyć wydziały teologiczne ze struktur uczelni państwowych, co wiązało się z masowymi powoływaniami do służby wojskowej wśród duchownych, seminarzystów oraz kleryków. Wreszcie, co zapewne z perspektywy instytucji kościelnych mogło być najgroźniejsze w skutkach, zapowiedziano antyreligijną ofensywę edukacyjną i ideologiczną wobec młodzieży ${ }^{15}$.

Podczas spotkania Politbiura zdecydowano ponadto o zwiększeniu inwigilacji Kościoła ze strony służb. Mówił o tym Ivan Krajačić „Stevo”, niezwykle zdolny organizator i pierwszy szef OZNY, który ówcześnie stał na czele MSW Chorwacji. Wskazywał on na słabość chorwackiej Komisji ds. Wyznań pod kierownictwem Ritiga. Działo się tak pomimo faktu, że w zasadzie sama Komisja, szczególnie w początkowym okresie jej działalności, stanowiła de facto „przybudówkę UDBY”16. Aleksandar Ranković, nadzorca i organizator służb, stał na stanowisku, że organ ten miał nazbyt mały wpływ na „walkę z religią” w kraju. Słowa te zapowiadały dalsze niekorzystne dla Kościoła katolickiego decyzje marszałka. W tych okolicznościach doszło do drastycznego zaostrzenia relacji pomiędzy Kościołem a władzami. Tito, obierając kurs na zerwanie z Watykanem, potrzebował odpowiedniego pretekstu, zatem siły państwa zostały ukierunkowane właśnie na ten cel.

14 Idem, Uzroci prekida diplomatskih odnosa između Vatikana i Jugoslavije 1952. godine, „Croatica Christiana Periodica" 2003, nr 52, s. 189-190.

15 R. Radić, Država i verske zajednice 1945-1970, t. 1, Beograd 2002, s. 346. Związkowa SKVP opracowała raport na temat działalności Kościoła katolickiego w Jugosławii, obszerną część poświęcając jego działaniom wśród młodzieży: AJ, SKVP, 144-136-740, Odnos države i katoličke crkve, s. 33 i nn. J. Tito zapowiadał rychłe ,rozwiązanie kwestii Stepinca” w wywiadzie udzielonym amerykańskiemu dziennikarzowi Drew Pearsonowi, 28 listopada 1951 r.; P. Vukman, The British Foreign Office on the situation of the Catholic Church in Yugoslavia, 1951-1953, „Chronica” 2009, t. 9-10, s. 204.

$16 \mathrm{~K}$. Buchenau, What went wrong? Church-State relations in socialist Yugoslavia, „Nationalities Papers" 2005, t. 33, nr 4, s. 550. 


\section{KAMPANIA PRASOWA \\ WOKÓŁ ZERWANIA STOSUNKÓW DYPLOMATYCZNYCH}

Nasilenie kampanii prasowej przeciwko Watykanowi nastąpiło w pierwszej połowie 1952 r. Jej celem było przygotowanie gruntu dla nadchodzących wydarzeń. Nie oznacza to oczywiście, że wcześniej nie pojawiały się negatywne w swoim wydźwięku teksty odnoszące się do Kościoła. W zasadzie od końca wojny głosy krytyczne były stale obecne w przestrzeni publicznej, mając za zadanie wywrzeć presję na stronę kościelną podczas toczących się rozmów przedstawicieli władz komunistycznych z kościelnymi. Natomiast w omawianym okresie publikowanie takich wypowiedzi nabrało charakteru skoordynowanego, objęło zasięgiem cały kraj, w szczególności regiony z większością katolicką, Chorwację i Słowenię.

Publikacje w prasie jugosłowiańskiej w 1952 roku umownie można podzielić wedle sześciu grup tematycznych. Należały do nich teksty związane z:

- papiestwem, kardynałami, strukturą wewnętrzną Kurii i polityką zagraniczną Stolicy Apostolskiej,

- relacjami watykańsko-jugosłowiańskimi,

- stosunkami pomiędzy Stolicą Apostolską a NDH,

- zerwaniem relacji dyplomatycznych ze Stolicą Apostolską,

- reakcjami społeczeństwa jugosłowiańskiego i zagranicy,

- osobą arcybiskupa/kardynała Alojzijego Stepinca.

Ta ostatnia kategoria publikacji prasowych jest najobszerniejsza. Tylko w grudniu 1952 r. w prasie jugosłowiańskiej ukazało się przynajmniej 129 różnego rodzaju artykułów o przeszłości kardynała, jak i sytuacji powstałej w następstwie jego nominacji na godność kardynalską, a także o międzynarodowych implikacjach tej decyzji. Łącznie daje to ponad $1 / 3$ wszystkich tekstów, jakie ukazały się w związku z zerwaniem relacji jugosłowiańsko-watykańskich. Od drugiego kwartału do końca 1952 r. w całej Jugosławii opublikowano przynajmniej 365 artykułów poruszających tematykę relacji z Watykanem (poza odnoszącymi się do Stepinca). Oczywiście liczba ta nie obejmuje innych tekstów, dotyczących pozostałych wyznań i religii, stosunku partii oraz „klasyków” komunizmu (Marks, Lenin) do religii, czy ogólniejszych relacji pomiędzy nauką a wiarą — których było przynajmniej kilkaset. Szacunkowo, od około 15 do 20 procent publikacji pojawiło się w gazetach o zasięgu ogólnokrajowym, zwłaszcza w darzonym powszechnym uznaniem tytule „Politika”, będącej organem KPJ „Borbie”, a także specjalistycznym periodyku społeczno-politycznym „Medjunarodna politika”. Publicystyka o ostrzu antykatolickim funkcjonowała także $\mathrm{w}$ mediach o zasięgu republikańskim w następującej kolejności: chorwackie, słoweńskie, bośniackie, serbskie i macedońskie. Częstym zjawiskiem było wzajemne przedrukowywanie tekstów publikowanych w poszczególnych republikach. 
W pierwszej fazie kampanii władze postawiły na „przypomnienie” społeczeństwu przewin hierarchii kościelnej sprzed i z okresu II wojny światowej. W serii artykułów zamieszczonych w różnych pismach przekonywano, że w zasadzie duchowni wszystkich szczebli we Włoszech, od kardynałów przez biskupów po w najmniejszym stopniu „zwykłych” księży, rozpalali entuzjazm włoskiego narodu do wojny przeciw Anglii i Francji, błogosławiąc wojenne emblematy czarnych koszul ${ }^{17}$. Podkreślano fakt, że papież Pius XII miał dążyć do

formalnej neutralności w konflikcie zbrojnym i ideowym. Ale jednocześnie zapowiedział, że zaakceptuje ustrój faszystowski, jeśli ten wygra. Papież nie potępił faszystowskiego porządku! Nic dziwnego, że faszystowska prasa jednoznacznie interpretowała tę neutralną ostrożność na rzecz faszy$\mathrm{zmu}^{18}$.

Przedstawiano wyrwane z kontekstu stwierdzenia, chętnie szafowano przykładami, niedopowiedzeniami — jakoby Pius XII popierał w pełni twierdzenia Mussoliniego, że wojna jest konieczna, by wydobyć najlepsze cechy czlowieka ${ }^{19}$.

W tym kontekście, niejako na potwierdzenie przytaczanych tez, „Vjesnik” szeroko komentował zrzucenie sutanny przez jezuitę i wysokiego dostojnika kościelnego Alighiero Tondiego, który wstąpił w szeregi Komunistycznej Partii Włoch w kwietniu 1952 r. Gazeta nie rozpisywała się rzecz jasna na temat przyczyn, które skłoniły duchownego do apostazji, natomiast uwypuklano jego słowa na temat kontaktów dostojników kościelnych z neofaszystami”.

Ponieważ Politbiuro KPJ, 15 stycznia 1952 r. zaleciło również „wzmożoną walkę” o dusze młodzieży, w skierowanym do tej grupy społecznej czasopiśmie „Mladina”20 pojawiła się seria artykułów przedstawiających politykę Watykanu w czasie II wojny światowej. W tym wypadku odnotowano wsparcie udzielone japońskiej polityce militarystycznej, poprzez postawę misjonarzy działających w Chinach podczas inwazji Japonii na ten kraj oraz przypadki kolaboracji przedstawicieli duchowieństwa z faszystowskimi reżimami w Europie (np. księdza Józefa Tisy na Słowacji). Zdaniem gazety, Kościół katolicki ponosił znaczną odpowiedzialność za rozpętanie II wojny światowej ${ }^{21}$.

17 Vatikan in fašizem, „Ljudska pravica” (10.05.1952). Tekst ten przedrukowano w „Vjesniku” (2324.05.1952). Podobne w treści artykuł: Politika Vatikana v drugi svetovni vojni, „Mladina” (04.08.1952).

18 Vatikan in fašizem.

19 Ibidem.

20 „Mladina” została założona w 1920 roku jako czasopismo lewicowej młodzieży słoweńskiej. W latach trzydziestych została zdelegalizowana, wznowiła regularną działalność w 1943 roku. Od 1945 roku stała się oficjalnym pismem słoweńskiej młodzieżówki komunistycznej SKOS (Savez komunističke omladine Slovenije).

21 A. Jager, Politika Vatikana v drugi svetovni vojni, „Mladina” (04.08.1952). 


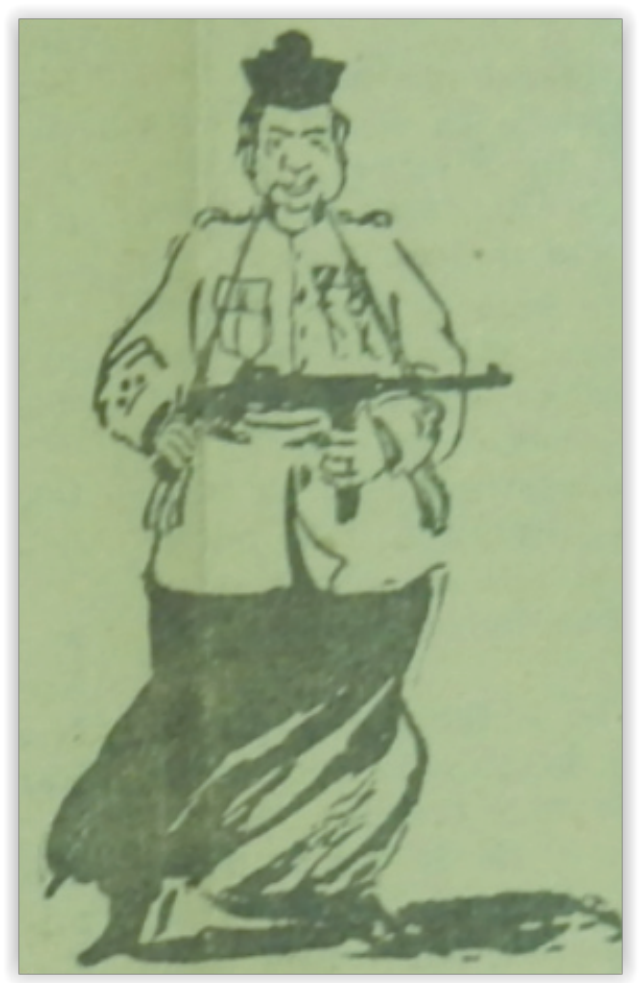

Ryc. 1. Karykatura zamieszczona na łamach czasopisma „Mladina”, odnosząca się do polityki Stolicy Apostolskiej w czasach II wojny światowej; Jager Ančka, Politika Vatikana v drugi svetovni vojni, „Mladina” (04.08.1952)

Równolegle nasileniu uległa narracja, za pomocą której starano się ukazać ścisłe relacje pomiędzy lokalnym episkopatem chorwackim, jak i Watykanem a ustaszami. Przodowały w tym przede wszystkim „Medjunarodna politika"22, analityczne pismo z tradycjami, wydawane do dziś oraz „Ljudska pravica"23, gdzie na kilka tygodni przed zerwaniem stosunków dyplomatycznych opublikowano serię wyselekcjonowanych dokumentów, jednoznacznie wskazujących na świadomą, pełną współpracę Kościoła z reżimem ustaszowskim. Działanie to było dopełnieniem personalnej kampanii prowadzonej przeciwko arcybiskupowi/ kardynałowi Alojzije Stepincowi, która posłużyła za bezpośredni pretekst do wydalenia legata papieskiego z Jugosławii. Warto podkreślić, że wątek ten relatywnie szybko został wygaszony. W styczniu 1953 r. ukazało się sześć artykułów na ten temat, a tylko jeden w marcu.

$\mathrm{W}$ prasie przedstawiono też papiestwu niezbędne warunki, po których spełnieniu stosunki państwowo-kościelne mogłyby się układać poprawnie. Choć autor artykułu w „Naši razgledi”, ukrywający się pod pseudonimem „Igrek”, pisał, że postawa Partii wobec kościoła jest bezsprzecznie negatywna, nie jest przyjacielska, jest wręcz przeciwnie, to jednak pośrednio sugerował możliwość koegzystencji. Mogłoby się tak stać, gdyby Kościół (a w zasadzie kręgi reakcyjnych watykańskich klerykałów) zmienił stosunek do ateistów (,Igrek" nie napisał, w jaki sposób), do partii oraz wszystkich członków Frontu Wyzwolenia, a także przestał się angażować w życie publiczne, wychowanie młodzieży itp. Choć „Igrek” nie miał nadziei na zmiany w tej materii, to przestrzegał, jak straszny los mógł spotkać komunistów gdyby władza znalazła się $w$ rękach (klerykałów; P.W.). Autor doszedł do wniosku, że światy idealistyczny oraz materialistyczny nie dawały się pogodzić, a jedyną możliwością było uznanie (przez

22 Vatikan u svetlosti dokumenata, „Medjunarodna politika” (01.11.1952, 16.11.1952, 01.12.1952).

23 Tajni dokumenti o odnosah Vatikana i ustaške NDH, „Ljudska pravica” (28.06.1952). 
Kościół) wszystkich naszych socjalistycznych praw. W przeciwnym bowiem razie dotychczasowe relacje należy radykalnie zmienić, a o zmianie tej postawy powinien zadecydować kościót watykański i jego zwolennicy ${ }^{24}$. Było to w zasadzie sparafrazowanie stanowiska Tity z rozmów z episkopatem chorwackim z czerwca 1945 r., podczas których marszałek za warunek unormowania relacji z władzą uznawał konieczność utworzenia struktur katolickich niezależnych od Watykanu.

W kampanii mającej na celu postawienie Watykanu w złym świetle nie mogło zabraknąc wątków finansowych. „Politika”, „Ljudska pravica”, „Večer” i inne periodyki szeroko rozpisywały się o problemach funkcjonowania Kurii Rzymskiej i nękających ją aferach korupcyjnych. Szczególnie upodobano sobie postać Bernardino Nogary, doradcy finansowego Stolicy Apostolskiej w latach 1929-1954, prowadzącego szerokie inwestycje i dbającego o zabezpieczenie interesów swoich mocodawców. W tekstach operowano przede wszystkim licznymi nazwami banków i oszałamiającymi kwotami (np. 500 miliardów lirów w akcjach). Taki obraz Kościoła, w który wpleciono jeszcze wątek „faszystowskich reżimów”, skierowany był do „przeciętnego” jugosłowiańskiego czytelnika, odczuwającego skutki kryzysu ekonomicznego w kraju ${ }^{25}$.

Kolejnym zabiegiem socjotechnicznym, stosowanym przez prasę jugosłowiańską, było odwoływanie się do powszechnych obaw obywateli związanych z powojennymi granicami państwa czy groźbą wynaradawiania Chorwatów i Słoweńców, którzy żyli we Włoszech. Tu również doszukiwano się negatywnej roli Kościoła katolickiego. Zajmowały się tym tytuły zarówno republikańskie, jak i centralne. W tekstach dominował ton oskarżycielski, mający wydźwięk wręcz histeryczny. W atakach na Watykan przodował przede wszystkim „Slovenski poročevalac”. W okresie od maja 1952 r. aż do końca tegoż roku, na 55 artykułów odnoszących się do tej tematyki 14 wydrukowano właśnie na jego łamach. Innymi aktywnymi w tej kwestii gazetami były „Vjesnik”, „Narodni list”, „Riječki list”, „Medjunarodna politika” i „Borba”. Autorzy, prócz podnoszenia kwestii Triestu, ostro atakowali „sprzeciw” Stolicy Apostolskiej wobec używania języka ojczystego w kościołach ${ }^{26}$. Był to jeden z istotnych aspektów polityki władz zmierzającej ku ,upaństwowieniu” wyznań.

Osobnym wątkiem były oskarżenia Watykanu o rzekomo tajny sojusz z rządem włoskim na szkodę granicznych (a także narodowych) interesów jugosłowiańskich. Nie bez przyczyny, ze względu na charakter gazety jako oficjalnego organu partii, w „Borbie” sam Tito formułował tezy o przyczynianiu się rzadu włoskiego do dominacji Watykanu poprzez szerzenie reakcji na świecie, a Watykan pomaga włoskim

24 „Igrek” podkreślił także konieczność lojalności Kościoła wobec państwa socjalistycznego. W zamian za to strona rządząca miała zapewnić „,swobodę obrzędów”. Takie lojalne porozumienie na pewno bytoby mite bogu — przekonywał autor [zachowano oryginalną pisownię - P.W.]; Igrek, Kateri odnosi so potrebni spremembe?, „Naši razgledi” (14.06.1952).

25 D. Čulić, Vatikan - eden največih finančnih mogotcev na svetu, „Ljudska pravica” (31.01.1953); Papežev tajnik in ukradenih 600 milijonov lir, „Večer” (07.10.1952); Finanska moć Svete Stolice, „Politika” (05.01.1953).

26 Vatikan protiv. narodnog jezika u crkvi, „Vjesnik” (13.07.1952, 14.07.1952, 18-19.07.1952). 
imperialistycznym aspiracjom wobec Jugosławii ${ }^{27}$. Wypowiedź tę uszczegółowił Kardelj, ale już na łamach chorwackiego „Vjesnika” dzień później. Posuwał się do jeszcze ostrzejszych metafor, że Watykan uznawat Bałkany i przez to terytoria narodów jugostowiańskich za wloska ,przestrzeń życiowa" ${ }^{28}$. Był to zatem dobrze przemyślany element kampanii ,informacyjnej”, zazębiający się i trzymający sprawdzonego wielokrotnie schematu przekazu polegającego na gradacji emocji.

\section{ZERWANIE Z WATYKANEM I KWESTIA ALOJZIJA STEPINCA}

Przyjęcie przez episkopat chorwacki, z inicjatywy Stepinca, listu pasterskiego Non licet (tłum. Nie można) w dniu 26 września 1952 r., będącego uszczegółowieniem stanowiska Piusa XII dotyczącego zakazu kolaboracji z władzami komunistycznymi przez duchownych, doprowadziło do zaostrzenia kursu Belgradu wobec Kościoła katolickiego. Dodatkowo, gdy Stolica Apostolska w dniu 29 listopada tego samego roku, ogłosiła nazwiska nominatów do godności kardynalskiej i znalazł się wśród nich arcybiskup zagrzebski, w ręce propagandystów jugosłowiańskich wpadł odpowiedni pretekst do zaostrzenia kampanii medialnej. Na nic zdała się oficjalna odpowiedź strony kościelnej, że nic nie stało na przeszkodzie w byciu katolikiem i jednocześnie lojalnym obywatelem swojego państwa. Decyzja o zerwaniu stosunków dyplomatycznych została wówczas ostatecznie podjęta, nic nie mogło wpłynąć na jej zmianę. Chodziło jedynie o stworzenie przeświadczenia w społeczeństwie, że całą winę za zaistniałą sytuację ponosił Watykan oraz jego najbardziej rozpoznawalny przedstawiciel w kraju, Stepinac ${ }^{29}$.

Jak wspomniano, w listopadzie i grudniu oraz na początku 1953 r. w prasie jugosłowiańskiej ukazało się przynajmniej 129 artykułów odnoszących się do Stepinca. $\mathrm{W}$ tekstach tych odpowiednio przedstawiono sylwetkę nowego kardynała, przy czym ich rozmieszczenie pod względem geograficznym było bardziej wyrównane niż w przypadku publikacji odnoszących się do innych tzw. kategorii tematycznych. Obok tytułów chorwackich, słoweńskich i ogólnojugosłowiańskich, o kardynale pisała „Nova Makedonija”, serbska (wojwodińska) „Slobodna Vojvodina” czy sarajewskie „Oslobodjenje”. Ważnym aspektem, podnoszonym przez publicystów, były opinie zagraniczne, mające sprzyjać linii jugosłowiańskiej. Tak też „Borba” informowała o „bezsprzecznych dowodach” na winę kardynała, które miały ukazać się np. w prasie brazylijskiej (Najveći brazilijski ilustrovani list o krivici Stepinca). Ten sam tytuł donosił w styczniu 1953 r. o sprawach opisywanych przez anglojęzyczne tygodniki, brytyjski „New Statesman”, o tradycjach sięgających 1913 r. (,, Nju Stejtsmen” donosi pismo Berleja o Stepinčevim zločinima) czy amerykański „Churchman” (Američki

\footnotetext{
27 „Borba” (18.12.1952); cyt. za: M. Akmadža, Katolička crkva, s. 147.

28 „Vjesnik” (19. 12.1952); cyt. za: M. Akmadža, Katolička crkva, s. 148.

29 V. Velikonja, Separation \& political intolerance, s. 195, 196.
} 
časopis „Čerčmen” objavljuje podatke o zločinima Stepinca). Wszystkie teksty miały ten sam wydźwięk, jednoznacznie ukazywały Stepinca jako świadomego i ścisłego współpracownika ustaszy, będącego też de facto wykonawcą woli Watykanu ${ }^{30}$. Niemniej istotne było ukazanie $\mathrm{w}$ mediach regionalnych i centralnych rzekomo masowego niezadowolenia społeczeństwa jugosłowiańskiego z polityki Stolicy Apostolskiej. I tak, „Slobodna Dalmacija” informowała w numerach z grudnia o masowych protestach robotników, wspierających władze, „między wierszami” pisząc o zdradzie, ale tym razem nie kardynała w kontekście jego współpracy z ustaszami, ale Jugosławii przez Watykan ${ }^{31}$.

Sam fakt zerwania stosunków dyplomatycznych pomiędzy Jugosławią a Stolicą Apostolską był przede wszystkim komentowany przez media centralne (głównie „Borbę” i „Politikę”). Z drugiej strony w gazetach lokalnych pojawiły się artykuły relacjonujące przebieg podejmowania tej decyzji, poprzez aklamację, w ramach Skupsztiny związkowej. Publikowano przemówienia najważniejszych polityków i ,analizy” oraz komentarze publicystyczne. „Borba” z dnia 19 grudnia w szerokich fragmentach cytowała głównego ideologa KPJ Edvarda Kardelja, ówcześnie ministra spraw zagranicznych. Na łamach czasopisma „Sperans” utrzymywał, że nieprzyjacielska polityka Watykanu występowała przeciwko najżywotniejszym interesom narodowym Jugosławii. Jak podkreślał,

nasza władza od początku była za swobodą wyznania (...). Prześladowania kościoła i religii są nie do pogodzenia z demokratyczną istotą naszego systemu, a rządzący w naszym kraju — choć ateiści zawsze dbali o to, aby religia pozostawała w sferze prywatnej, której nie można wymazać prześladowaniami ani dekretami, nawet jeśli się tego chce ${ }^{32}$.

Nie zmieniało to jednak faktu, że Watykan w oczach E. Kardelja stanowił wręcz egzystencjalne zagrożenie dla Jugosławii, reprezentując ekspansjonistyczne tendencje kręgów włoskich. Kardelj wskazał też przyczynę trudnego położenia duchowieństwa katolickiego w Jugosławii — sprzeciw Stolicy Apostolskiej wobec normalizacji swojej sytuacji, choć i tak była ona lepsza niż w niejednym rozwiniętym państwie europejskim $^{33}$. Komuniści, nie tylko jugosłowiańscy, często odwoływali się do idei sprowadzenia religii sfery prywatnej. W praktyce, służyło to rugowaniu z przestrzeni publicznej symboli religijnych i dyskryminowaniu wierzących poprzez różne utrudnienia administracyjne.

30 Chorwacki „Vjesnik” starał się pokazać kardynała jako osobę skompromitowaną zarówno wśród wiernych, jak i duchowieństwa. Ukazała się seria artykułów na ten temat (Još nešto o liku novopečenog kardinala), w której opisywano postawę A. Stepinca w latach międzywojennych i podczas wojny. Sugerowano m.in., że duchowny nie stawiał w obronie księży więzionych przez Niemców i ustaszy (Ni za zatočene svećenike nije se htio zauzeti).

31 „Slobodna Dalmacija” (06.12.1952, 08.12.1952, 11-12.12.1952).

32 E. Kardelj, Referat druga Kardelja o prekidu diplomatskih odnosa sa Vatikanom, „Borba” (19.12.1952).

33 Ibidem. 
Do frontalnej krytyki Stolicy Apostolskiej i Kościoła katolickiego „spontanicznie" przyłączali się poszczególni deputowani Skupsztyny i ważni politycy, w tym Petar Stambolić (ówcześnie premier Serbii) czy społecznik Josip Šestan. Ten drugi twierdził, że Stepinac jako zbrodniarz pierwszego rzędu zastużyt nie tylko na więzienie, ale na śmierć. Były duchowny prawosławny Vlada Zečević, jednocześnie pierwszy powojenny minister spraw wewnętrznych w okresie od marca 1945 do lutego 1946 r., od strony moralnej recenzował postawę wyższego duchowieństwa katolickiego i szerzej Watykanu podczas II wojny światowej, mówiąc: Ale szczęściem dla ludzkości jest, że oprócz chrześcijańskiej istnieje jeszcze inna moralność. Jest niq moralność ludzka, przemawiająca za zbliżeniem narodów Jugostawii (w kontekście ludobójstwa z czasów II wojny światowej — P.W.) (...) realizowanej przez towarzysza Tito. Ze strony macedońskiej głos w tej sprawie zabrał wpływowy polityk, publicysta i pisarz Vlado Maleski, z całego serca popierając decyzję naszych władz ${ }^{34}$.

Gazety lokalne z kolei starały się udowodnić, że „zwykli” katolicy nie akceptowali ,agresywnej polityki Watykanu”. Słoweński „Kmečki glas” opublikował fragmenty rozmowy z kanonikiem przy diecezji mariborskiej Alojzijem Ostercem, w której duchowny, odpowiadając na pytanie dziennikarza o relacje pomiędzy państwem a Kościołem, stwierdził: Życzyłbym sobie, jako przyktadny obywatel $i$ katolik, by w relacjach (państwowo-kościelnych — P.W.) wypracować modus vivendi, zaakceptowany przez obie strony. Zainteresowany jest tym Kościót, by uspokoić sumienia swoich wiernych, a także państwo, któremu zależy na zadowoleniu jak największej liczby swoich obywateli ${ }^{35}$.

Niewątpliwie nadrzędnym celem propagandy jugosłowiańskiej na szczeblu centralnym i lokalnym było przerzucenie odpowiedzialności za zerwanie stosunków na stronę watykańską. Nie było to zadanie trudne przynajmniej w przypadku tej części społeczeństwa, która odwoływała się do prawosławia. Mam tu na uwadze uwarunkowania historyczne, a zwłaszcza wspomnienia odnoszące się do czasów II wojny światowej, a także kontrowersji w sprawie konkordatu, podpisanego w 1935 roku przez władze międzywojennego Królestwa Jugosławii. Umowa ta nie weszła w życie w obliczu ostrego sprzeciwu Serbskiej Cerkwi Prawosławnej ${ }^{36}$.

W ówczesnej prasie odnaleźć można wiele entuzjastycznych relacji, które miały oddawać „spontaniczne”, pozytywne reakcje społeczeństwa jugosłowiańskiego na zerwanie stosunków dyplomatycznych ze Stolicą Apostolską. Biorąc pod uwagę datę zerwania relacji (17 grudnia), zrozumiałe jest, że część tekstów z tej kategorii ukazywała się jeszcze na początku 1953 roku. W tytułach publikacji, które ukazały się

34 Diskusija u spoljno-političkom odboru Narodne skupštine, „Borba” (19.12.1952).

35 Zakai je Jugoslavija prekinila diplomatske odnose z Vatikanom, „Kmečki glas” (24.12.1952).

36 Szerzej o tej problematyce pisze: M. Ninčević, Diplomatski odnosi Vatikana i Kraljevine Jugoslavije: konkordat iz 1935. godine, „Nova prisutnost” 2016, nr 14 (2), s. 299-307. 
na łamach takich pism, jak „Slobodna Vojvodina”37, „Oslobodjenje”38, „Jednota”39 (Jedność — pismo mniejszości czeskiej), „Hrvatska riječ”40 czy „Primorske novice"41, akcentowano, jak słuszną decyzję podjęły władze w Belgradzie. Zdaniem dziennikarzy „lud spontanicznie” wyrażał swoje zadowolenie, uwypuklano pozytywne stanowisko mniejszości religijnych względem polityki władz. Ważne było pokazanie, że ,postępowe” stowarzyszenia księży katolickich ze Słowenii, Bośni i Hercegowiny czy Czarnogóry także popierały jugosłowiański punkt widzenia, upatrując w działalności episkopatu chorwackiego i słoweńskiego spisek, jakim ponoć miano kierować z Watykanu. „Politika” i „Dnevnik” przytaczały stanowisko słowackich ewangelików, którzy popierali jugosłowiańską politykę wyznaniową, nazywając ją wręcz wzorcową ${ }^{42}$.

$\mathrm{Na}$ potrzeby państwowej propagandy wykorzystano wypowiedzi biskupa ewangelickiego Samuela Štarka ${ }^{43}$, przewodniczącego stowarzyszenia Macierz Słowacka w Jugosławii. Duchowny wyraził całkowite poparcie dla władz na łamach „Dnevnika”44. Na uwagę zasługuje użycie wyrażenia ,nasze władze” w tytule publikacji, w której zacytowano stanowisko pastora.

Publikacje z ostatniej kategorii, dotyczące reakcji zagranicy na zerwanie stosunków jugosłowiańsko-watykańskich, obejmują 28 tekstów, które ukazały się w okresie trzech tygodni. Miały pokazywać szerokie zrozumienie dziennikarzy z całego świata dla polityki władz w Belgradzie. Specjalizowały się w tym przede wszystkim media centralne, posiadające korespondentów bądź odpowiednie zaplecze intelektualne i techniczne. Na łamach gazet pojawiły się relacje ze Szwajcarii, RFN, Wielkiej Brytanii, Grecji, Belgii, Francji, Turcji czy Stanów Zjednoczonych. Brak reakcji ze strony prasy z bloku radzieckiego należy tłumaczyć trwającym wówczas konflik-

37 Gradjani Kikinde pozdravljaju odluku Savezne vlade o prekidu diplomatskih odnosa sa Vatikanom, „Slobodna Vojvodina” (19.12.1952).

38 Katolički svećenici u Hercegovini odobravaju prekid diplomatskih odnosa s Vatikanom, „Oslobodjenje" (22.12.1952).

39 Zbesilou štvanici proti Jugoslavii Vatikan podporuje imperijalisticke snahy Rima, „Jednota” (26.12.1952) Wydawcą tego tytułu (od 1946 roku) był Związek Czechów z miasta Daruvar. Tytuł nawiązywał do pisma „Narodna jednota” (jedność narodowa), wydawanego w okresie międzywojennym. Nakład „Jednoty” wahał się od dwóch do trzech tysięcy egzemplarzy. Więcej o gazetach mniejszości narodowych: K. Spehnjak, Uloga novina u oblikovanju javnog mnijenja u Hrvatskoj 1945.-1952., „Časopis za suvremenu povijest" 1993, nr 25 (2-3), s. 165-181.

40 Zajednička izjava slovenskih svećenika devinsko-nabrežinske općine, „Riječki list” (23.12.1952).

41 Nikoli ne bomo dopustili da bi se Vatikan vmešaval v naš̌e notranje zadeve, „Primorske novice" (09.01.1953).

42 Udruženje slovačkih evangeličkih sveštenika o saradnji države $i$ crkve i prekidu odnosa sa Vatikanom, „Politika” (08.02.1953).

43 Więcej o działalności S. Štarka i mniejszości słowackiej w Jugosławii: M. Sovilj, Činnost slovenské menšiny v Jugoslávii proti Slovenskému státu v letech 1939-1941: Př́spěvek k jugoslávsko-slovenským vztahům na začátku druhé světové války, [w:] Človek, spoločnost', doba. Stretnutie mladých historikov III, red. Z. Tokárová, M. Pekár, Košicie 2014, s. 183-196.

44 Potpuno se slažem sa stavom naše Vlade, „Dnevnik” (17.01.1953). 
tem politycznym pomiędzy KPJ a Kominformem. Oczywiście większość przytaczanych przez gazety przychylnych władzom jugosłowiańskim opinii pochodziła ze środowisk socjalistycznych bądź komunizujących, działających na Zachodzie ${ }^{45}$. Duże zainteresowanie kwestia ta wywołała także w Turcji, gdzie bliskie władzy dzienniki wspierały postępowanie Belgradu z uwagi na oficjalnie deklarowaną laickość Republiki Tureckiej ${ }^{46}$. Tego typu poparcie było szczególnie istotne propagandowo dla Jugosławii, która natenczas pozostawała w izolacji międzynarodowej. $Z$ jednej strony była wykluczona z Kominformu, z drugiej z trudem próbowała otworzyć się na kontakty z Zachodem.

Decyzja o zerwaniu stosunków jugosłowiańsko-watykańskich, podjęta w styczniu 1952 r., była błędem politycznym Tity. Marszałek zmuszony był zaprzeczyć swoim słowom, że czas gra na jego korzyść w konflikcie ze stroną kościelną. Przemodelowanie jugosłowiańskiej polityki zagranicznej, otwarcie kraju na świat, a przede wszystkim ambicje Tity aby odegrać poważną rolę w polityce światowej sprawiły, że błędy przeszłości należało naprawić, wypracowując pokojowy modus vivendi z Watykanem. Nastąpiło to w $1966 \mathrm{r}$. Z pewnością decyzja z 1952 roku nie wpłynęła jednak na przebieg wizyty marszałka w Wielkiej Brytanii (16-21 marca 1953 r.). W lutym i marcu w Zjednoczonym Królestwie ukazała się seria gloryfikujących go publikacji prasowych, a środowiska katolickie z Londynu na próżno starały się skłonić premiera Winstona Churchilla do poruszenia sprawy losu katolików w Jugosławii. Za zrozumieniem przyjmowano w Londynie (a także w Waszyngtonie) oświadczenia strony jugosłowiańskiej, że lokalni hierarchowie katoliccy popierali ustaszy i faszystowskich okupantów ${ }^{47}$.

O ile członków samej partii komunistycznej nie trzeba było przekonywać co do słuszności polityki władz (wszelka opozycja wewnętrzna była eliminowana począwszy od 1948 r.), to w przypadku ogólniej pojętego społeczeństwa sytuacja wyglądała inaczej. Warto pamiętać, że Jugosławia pod względem konfesyjnym była krajem unikatowym, żadne z trzech głównych wyznań nie stanowiło znaczącej większości. Ponadto w Chorwacji, ale także w innych częściach federacji, instytucje kościelne nie zostały do końca złamane. Nawet zdominowana przez aparat państwowy

45 „Popiler” kritikuje tradicionalnu neprijateljsku politiku Vatikana (odjek u Francuskoj), „Borba” (25.12.1952); Članak belgijskog socijaliste o Jugoslaviji, „Borba” (08.12.1952) — o konflikcie pomiędzy Jugosławią a Stolicą Apostolską; Švajcarski listovi osudjuju neprijatelsku politiku Vatikana prema Jugoslaviji, „Borba” (31.12.1952).

46 Mowa np. o gazecie wydawanej w Ankarze „Zafer” (zwycięstwo) czy organie nacjonalistycznej Republikańskiej Partii Ludowej, ukazującym się pod tytułem „Ulus” (naród); „Zafer” o intrigama Vatikana, „Narodni list” (04.01.1953); Po prekinitvi z Vatikanom, „Ljudska pravica” (31.12.1952); Turski list ,Ulus” ističe antijugoslovensku delatnost Vatikana, „Borba” (24.12.1952).

${ }^{47}$ Bezprecedensowego wsparcia dla polityki J. Tity wobec Kościoła katolickiego udzieliły niektóre wspólnoty protestanckie z USA, na czele z Światową Federacją Luterańską. Jej przedstawiciele stwierdzili nawet, że pomiędzy państwem jugosłowiańskim a kościołami były zorganizowane podobnie jak w Ameryce; K. Spehnjak, Tito 's visit to Great Britain in 1953, ,, Review of Croatian History” 2005, nr 1(1), s. 277, 280-281; P. Vukman, The British Foreign Office, s. 203-212. 
Serbska Cerkiew Prawosławna i społeczność muzułmańska (w szczególności wśród Albańczyków w Macedonii) powoli, acz w sposób jak się okazało nieuchronny, stopniowo odzyskiwały swoje wpływy. Wyrażało się to np. poprzez wzrost liczby słuchaczy różnego rodzaju szkół wyznaniowych, i to pomimo postępującej laicyzacji społeczeństwa.

Funkcję „,edukacyjną” w stosunku do ludności, co naturalne, przejęły środki masowego przekazu, a zwłaszcza prasa. Ostrze propagandy władz było nakierowane na republiki z dużym udziałem wyznawców katolicyzmu, czyli na Chorwację i Słowenię. Odnosząc się do treści, materiały publikowane w lokalnych periodykach były tendencyjne, powielały powszechnie znane argumenty władz i utarte schematy. Takie uproszczony przekaz trafiał do znacznej części społeczeństwa, padając na podatny grunt zwłaszcza tam, gdzie istniał wrogi resentyment wobec katolicyzmu i relatywnie niskie było wykształcenia odbiorców. Propaganda była jednym z elementów dopełniających politykę władz, zmierzała do odebrania niezależności Kościołowi katolickiemu w Jugosławii. Bazowała na powszechnych stereotypach i lękach, dzięki temu miała zaistnieć w powszechnej świadomości.

Warto podkreślić, że zadanie postawione przed osobami odpowiedzialnymi za prasową kampanię antykatolicką było niezwykle delikatne. W $1953 \mathrm{r}$. w całej Jugosławii za ateistów uznawało się (,tylko”) nieco ponad 12 procent obywateli, co świadczyło o nadal relatywnie silnej pozycji religii wśród społeczeństwa jugosłowiańskiego. Ponieważ tradycyjne podziały narodowe w dużej mierze pokrywały się z różnicami religijnymi, w przekazie prasowym starano się abstrahować od waśni narodowościowych i wskazywać przede wszystkim na „kolaboracyjną” aktywność Kościoła katolickiego. Bardziej rozbudowane pod względem treści ataki na tę instytucję kościelną mogły wzmocnić istniejące podziały, co godziłoby w fundament założycielski komunistycznej Jugosławii i ideę „braterstwa i jedności” (bratstva $i$ jedinstva). Właśnie $\mathrm{z}$ tego powodu $\mathrm{w}$ ówczesnych tekstach prasowych unikano zwrotów, które mogły wskazywać narodową przynależność krytykowanych hierarchów.

\section{BIBLIOGRAFIA}

\section{Źródła archiwalne}

Arhiv Jugoslavije, zespół nr 144 (Savezna komisija za verska pitanja).

\section{Opracowania}

Akmadža M., Biskupi, komunisti i svećenička udruženja, Zagreb-Sarajevo 2018.

Akmadža M., Katolička crkva u komunističkoj Hrvatskoj 1945-1980, Zagreb-Slavonski Brod 2013.

Akmadža M., Riječju i djelom, Zagreb 2019.

Akmadža M., Uzroci prekida diplomatskih odnosa između Vatikana i Jugoslavije 1952. godine, „Croatica Christiana Periodica” 2003, nr 52, s. 171-202; https://hrcak.srce.hr/11909 [dostęp: 10.08.2021].

Alexander S., Church and state in Yugoslavia since 1945, London 1979.

Alexander S., The Triple myth: a life of archbishop Stepinac, Boulder 1987. 
Buchenau K., What went wrong? Church-State relations in socialist Yugoslavia, „Nationalities Papers” 2005, t. 33, nr 4, s. 547-567.

Dedijer V., Josip Broz Tito. Prilozi za biografiju, Beograd 1953.

Dimitrijević B., Intelligence and security services in Tito's Yugoslavia 1944-1966, „Istorija 20. veka” 2019, nr 2, s. 9-28.

Dimitrijević B., Kontraobaveštajna služba jna na području Hrvatske 1944-1968., [w:] Jugoslavija između ujedinjenja i razlaza. Hrvatsko-srpski odnosi u kontekstu društvenoj razvoja dve Jugoslavije 1918 1991., red. B. Dimitrijević, M. Jareb, Beograd 2018, s. 141-160.

Jandrić B., Položaj katoličke crkve u Hrvatskoj u poslijeratnim godinama (1945.-1953.), „Croatica Christiana Periodica" 1998, nr 42, s. 49-62, https://hrcak.srce.hr/109301 [dostęp: 10.08.2021].

Janjić J., Srpska crkva u komunizmu i postkomunizmu (1945-2000), Beograd 2018.

Lučić I., Komunistički progoni katoličke crkve u Bosni i Hercegovini 1945-1990., „National Security and the Future" 2008, nr 3(9), s. 41-71, https://hrcak.srce.hr/30691 [dostęp: 10.08.2021].

Maticka M., Zakonski propisi o vlasničkim odnosima u Jugoslaviji (1944-1948), „Radovi Zavoda za hrvatsku povijest Filozofskoga fakulteta Sveučilišta u Zagrebu” 1992, t. 25, nr 1, s. 123-148, https:// hrcak.srce.hr/51101 [dostęp: 10.08.2021].

Nikolić K., Mač revolucije: OZNA u Jugoslaviji 1944-1946, Beograd 2014.

Ninčević M. M., Diplomatski odnosi Vatikana i Kraljevine Jugoslavije: konkordat iz 1935. godine, „Nova prisutnost" 2016, nr 14 (2), s. 299-307.

Radić R., Država i verske zajednice 1945-1970, t. 1, Beograd 2002. [Радић R., Држава и верске заједнище 1945-1970., t. 1, Београд 2002].

Sovilj M., Činnost slovenské menšiny v Jugoslávii proti Slovenskému státu v letech 1939-1941: Přispěvek k jugoslávsko-slovenským vztahuim na začátku druhé světové války, [w:] Človek, spoločnost', doba. Stretnutie mladých historikov III, red. Z. Tokárová, M. Pekár, Košicie 2014, s. 183-196.

Spehnjak K., Uloga novina u oblikovanju javnog mnijenja u Hrvatskoj 1945.-1952., „Časopis za suvremenu povijest" 1993, nr 25(2-3), s. 165-181, https://hrcak.srce.hr/210124 [dostęp: 10.08.2021].

Spehnjak K., Tito's visit to Great Britain in 1953, „Review of Croatian History” 2005, nr 1(1), s. 273-294, https://hrcak.srce.hr/22500 [dostęp: 10.08.2021].

Tondi A., Vatikan und Neofaschismus, Berlin 1959.

Tondi A., Władza tajemna Towarzystwa Jezusowego, Warszawa 1953.

Velikonja V., Separation \& political intolerance in Bosnia-Herzegovina, College Station 2003.

Vukman P., The British Foreign Office on the situation of the Catholic Church in Yugoslavia, 1951-53, „Chronica” 2009, t. 9-10, s. 203-212.

Wawryszuk P., Działalność Państwowej/Zwiazkowej Komisji ds. Wyznań w Jugosławii w latach 19451971, „Dzieje Najnowsze” 2018, nr 4, s. 79-95.

Wawryszuk P., Jugostawia, [w:] Sprawiedliwość, zemsta i rewolucja. Rozliczenia z wojna i okupacja w Europie Środkowo-Wschodniej, red. A. Paczkowski, Gdańsk 2016, s. 97-129.

Zacharias M., Komunizm, federacja, nacjonalizmy: system władzy w Jugostawii 1943-1991: powstanie, przekształcenia, rozkład, Warszawa 2004.

Zečević M., Popović J., Dokumenti iz istorije Jugoslavije: Državna komisija za utvrđivanje zločina okupatora i njegovih pomagača iz drugog svetskog rata, t. 2, Beograd 1998.

Žutić N., Nadbiskup Stepinac. Ideologija i politika 1934-1946, Beograd 2017.

\section{Prasa}

„Borba”

„Dnevnik”

„Hrvatska riječ”

„Jednota”

„Kmečki glas"

„Ljudska pravica"

„Medjunarodna politika” 
„Mladina”

„Narodni list”

„Naši razgledi”

„Nova Makedonija”

„Oslobodjenje”

„Politika”

„Primorske novice”

„Riječki list”

„Slobodna Dalmacija”

"Slobodna Vojvodina"

„Slovenski poročevalac"

„Vjesnik” 